\title{
Drivers of Success for Community Based Natural Resource Projects in Coast Region of Kenya
}

\author{
NyiroCharles Wanje ${ }^{1 *}$, Amani Michael Nyiro² and NyiroRobert ${ }^{3}$ \\ ${ }^{1}$ Research East Africa Consultants, Kilifi, Kenya \\ ${ }^{2}$ Department of Environmental Resource Conservation, Kenyatta University, Kenya \\ ${ }^{3}$ Department of Business, Technical University of Kenya, Kenya
}

Submission: July 02, 2017; Published: July 28, 2017

*Corresponding author: NyiroCharles Wanje, Research East Africa Consultants, Kenya, Email: cnyiro@gmail.com

\begin{abstract}
The paper is part of a World Bank funded study on documentation of community based natural resource management (CBNRM) projects in the Coastal region of Kenya. The paper takes a look at the drivers of success for community based natural resource projects. The drivers of success are discussed in this paper because they address some of the objectives of the study. The study was prompted by the realization that there are many initiatives under taken by environmental and natural resource management projects that have the potential to serve as a showcase for the benefits of conserving natural resources. A key attribute to achieving this is to ensure quality documentation of these initiatives and their drivers of success. It is because of this that this researcher undertook documentation of the drivers of success in order to generate the information needed to stimulate uptake and adoption with the aim of disseminating the information on such projects to various segments of the coastal communities for uptake.
\end{abstract}

The study involved 40 participants representing 40 CBNRM groups and five FGDs comprising 5-10 participants drawn from five CBNRM groups. Data was collected using interviews, document reviews, observations and focused group discussions. After collection the data was analysed both thematically and numerically and presented using descriptive statistics. All relevant ethical issues were considered. The study provides a basis upon which environmental and natural resource projects can emulate in order to be successful. It also fills a gap in the existing literature as well as contributing towards the continuing discourse on natural resource management.

Keywords: Natural resource management; Drivers of success; CBNRM Groups; Communication, Documentation; Kenya Coastal Development Project; World Bank

Abbreviations: ACC: African Conservation Centre; ACES: Association for Coastal Ecosystem Services; ANO: The Africa Nature Organization; AWF: African Wildlife Foundation; BMU: Beach Management Unit; CBC: Community Based Conservation; CBNRM: Community Based Natural Resource Management; CBOs: Community Based Organizations; CDA: Coast Development Authority; CDTF: Coast Development Tourism Fund; CITES: Convention on International Trade in Endangered Species of Wild Fauna and Flora; CWS: Community Wildlife Services; EAWS: East African Wildlife Society; EU: European Union; FGDs: Focus Group Discussions; GOK: Government of Kenya

\section{Background}

\section{Introduction}

The Government of Kenya received financing from the International Development Association (IDA) and the Global Environment Facility (GEF) towards the Kenya Coastal Development Project (KCDP) applied part of the proceeds to finance a Consultancy Service to document and disseminate successful community based natural resource sub-projects. KCDP covers a period of 6 years and was in its third year of implementation with a development objective of improving management effectiveness and enhancing revenue generation of Kenya's coastal and marine resource.
The project is comprised of the following four components:

a. Component 1: Sustainable Management of Fisheries Resources;

b. Component 2: Sound Management of Natural Resources;

c. Component 3: Support for Alternative Livelihoods; and

d. Component 4: Capacity building, Monitoring and Evaluation System, Project Management and Communication, Development Fund of the Coast. 
The project was implemented by 7 agencies of the Government of Kenya (GoK), comprising of Kenya Marine and Fisheries Research Institute, State Department of Fisheries, Kenya Wildlife Service, Kenya Forestry Research Institute, Coast Development Authority, Ministry of Lands and National Environmental Management Authority. The activities of these agencies, within the KCDP project, are coordinated by a centralized Project Coordinating Unit (PCU) based at Kenya Marine and Fisheries Research Institute (KMFRI).This paper relates to Component two (Sound Management of Natural Resources).

\section{Rationale for the project}

Under component 2 (Environmental governance and integrated coastal management), KCDP was promoting the uptake and adoption of best practices in natural resource management. In order to generate the information needed to stimulate uptake and adoption, the project sought to identify, evaluate and analyse successful community based natural resource projects in the coast region with the aim of disseminating the information on such projects to various segments of the coastal communities for uptake.

\section{KCDP and Sustainable development in the Coastal community}

Kenyans living in Coast province are among the poorest in the country, despite the province's considerable potential for economic growth from tourism, fisheries and other investments. KCDP project has helped to increase economic opportunities for coastal communities by promoting environmentally-sustainable tourism and fisheries, equitable sharing of tourism and fisheries revenues, and investment in rural micro, small and medium-sized enterprises. The project has promoted sustainable management of tourism and fisheries resources in line with the government's Vision 2030, which identifies tourism as an engine of growth, job creation, poverty reduction and wealth generation in the Coastal region. It has supported governance reforms of fisheries management in an exclusive economic zone and promoted research in near-shore fish stocks to increase sustainable and profitable fishing practices.

The KCDP project has also improved the management and regeneration of natural resources and biodiversity of the Coastal and marine environments, reflecting the environmental sustainability theme of the World Bank's Country Partnership Strategy for Kenya. These objectives are complemented by sustainable livelihoods in a sound governance framework including spatial planning and land capability mapping, integrated coastal management and compliance with regulations and safeguards. The project has also promoted dialogue amongst national partners and regional stakeholders, and established a Community Village Fund to build capacity of micro projects through grants.
Further, the KCDP project has the potential to positively affect Kenya's coastal region, with far reaching changes in the livelihoods of the people at the Coast. This, however, can only happen if the inhabitants of the coast see the opportunity and participate in the project. Other than improving the livelihoods of the coastal inhabitants, the project has far-reaching effects beyond the coast. It has the potential to serve as a showcase for the benefits of conserving natural resources. A key attribute to achieving this is to ensure quality documentation of these initiatives. In the past, conservation of biodiversity was carried out by establishing parks and zoos and creating strict laws regarding the use of wild plants and animals. This form of natural resource management was costly and inefficient. In last decade, awareness has grown regarding the close links between biodiversity loss, human population and poverty.

It is now commonly accepted that the people who live in close contact with, and are dependent upon, wild plants and animals for their survival must be fully involved in all efforts to find solutions to address biodiversity loss. The latter forms the principle of what has evolved into Community Based Natural Resource Management (CBNRM), which is a paradigm shift in conservation and natural resource management. The goals of CBNRM are to increase resource user participation in NRM decisions and benefits by restructuring the power relations between central state and communities through the transfer (devolution) of management authority to local level organizations. The CBNRM is compatible with the International treaties as it has a framework for integrating with economic and social development. Participation in development is a process through which people with a legitimate interest (stakeholders) influence and share control over development plans and decisions and resources that affect them. In the recent past, various countries have been redefining natural resource management to directly engage local communities. For instance in Tanzania, the Wildlife Conservation policy [1] moves beyond the outreach efforts of community conservation employed by the Tanzania National Park Authority (TANAPA) by proposing real engagement through community based conservation WD [2]. Amongst other countries which have adopted CBNRM approaches are India, China, USA, Namibia, Botswana, South Africa, Malawi, Zambia and Lesotho Shackleton et al. [3].

\section{Natural Resource Management}

Natural Resource Management is the management of natural resources such as land, water, soil, plants and animals, with particular focus on how the management affects the quality of life for both present and future generations. Natural Resource Management is congruent with the concept of sustainable development, the principle that forms the basis for sustainable global land management and environmental governance to conserve and preserve natural resources. Natural resource management specifically focuses on scientific and technical 
understanding of resources and ecology and the life supporting capacity of those resources.

Natural resource management lays emphasis on sustainability and can be traced back to the early attempts to understand the ecological nature of American rangelands and resource conservation. In the 20th Century the concept took a more holistic, national and even global form culminating in the Brund land Commission and the advocacy of sustainable development Brund land, [4]. At that time the state had a controlling role in formulation and management of NRMs. In many cases these systems led to failure and disillusionment as they were protectionist styles of management Lyons, Lewis \& Carter $[5,6]$.

In addition the colonial-era management practices based on "fines and fences" frequently failed to achieve conservation goals because they alienated people from their traditional resource base, thereby reducing the economic and social value of natural resources and causing over-exploitation and mismanagement. Finally, the state management system had inherent weakness as it was seen as a domain of either state sector institutions endowed with appropriate authority, expertise and other resources or private sector institutions pursuing individual economic interests and benefits. These weaknesses led to the paradigm shift from state-controlled NRM into Community Based Conservation groups (CBC).

\section{Community Based Conservation}

Community Based Conservation (CBC) became the recognized trademark of what many claimed was a "new conservation" unfolding across Africa Hulme and Murphee [7,8]. In response to the recognized failure of top-down approaches to development and ecological limits of protectionist ("fortress") conservation, "the community" has now become the catchall solution for effective conservation and development Western ,Wright, McNeely, McNaughton [9,10]. CBC shifts the focus of conservation from nature as protected through exclusive state control to nature as managed through inclusive, participatory, community-based endeavors. To effectively make this shift, CBC devolves natural resource management to local communities and hence is often referred to as community-based natural resource management.

\section{Community Based Natural Resource Management}

Community based Natural Resource Management (CBNRM) is an approach to conservation and development that recognizes the rights of the local people to manage and benefit from the management and use of natural resources. It entails transferring back to communities' access and use rights, empowering them with legislation and devolved management responsibilities, building their capacity and creating partnerships with public and private sector actors to develop programmers for the sustainable use of a variety of natural resources.
Many traditional systems of natural resource tenure are known to have been sustainable and even beneficial for conservation. There is need therefore to enable this tradition to continue despite modern changes in economy and society. CBNRM concept addresses both human and natural resource issues such as the long term benefits of present and future generations given the inefficiency of state management. In addition, CBNRM addresses objectives such as equity, poverty alleviation and empowerment of marginalized user communities. The management concept focuses on communities for assessing natural resource uses, potentials, problems, trends and opportunities. In addition it also takes action dealing with adverse practices and dynamics with corporation and support from other actors linked horizontally (e.g. other communities) and vertically (e.g. higher level or external entities such as local or district government, regional bodies, government agencies, non-governmental organizations (NGOs), Universities or other organizations that have interest in resource conservation and management.

The Key elements of CBNRM include detailed operation plans developed and agreed to by all concerned stakeholders. In addition, the approach is that communities are backed by a legal framework on rights, benefits and economic incentives to take substantial responsibility for sustained use of resources. The CBNRM groups operate under the following principles Bond et al. [11]

a. The benefits of managing a resource should exceed the costs and the resource must have a measurable value to the community.

b. Communities living with the resource should receive higher benefit than those who do not.

c. Smaller groups are more likely to better manage their resource than larger groups.

d. The community that lives with the resource should also be the group that makes the decisions over the resource and the same as the group that benefits.

e. Communities should benefit from practicing good management. Similarly, when communities do not invest in management, then the benefits should fall.

The main benefits accruing from adopting these measures can be categorized into direct and indirect benefits. Direct benefits include investments in rural infrastructure through community based projects, direct cash dividends and from partnerships, employment opportunities with private sector, employment opportunities with CBOs, indirect benefits maintenance or growth of stocks of natural resources, capacity building, opportunities to diversify local economy and integration into the local market.Despite the process towards devolution in the process of natural resource management the 
central governments still maintains a role; protecting the wider "public goods" such as watersheds, biodiversity carbon sinks and other ecological services; establishing the policy, legal and social frameworks and conditions needed for local management to succeed; mediating conflicts; providing technical assistance; facilitating and regulating private activity; addressing local inequalities of marginal groups so that downward accountabilities of organizations receiving devolved authority is assured; helping communities to defend their rights including protection against powerful external groups such as mining and timber companies and organized traders and supporting local capacity among others Shackleton et. al. [3].

In the Maasai Mara - Serengeti ecosystem the concept of CBNRM is gaining ground. For instance Tanzania has redefined its wildlife conservation agenda to directly engage local communities Goldman [12]. In Kenya, there has been increased involvement of local communities in the management of local resources especially around protected areas e.g. through KWS community wildlife service and specific projects implemented by NGOs and Government agencies in different areas and involving different resources. Community Based Natural Resource Management (CBNRM) is still relatively new in Kenya. Therefore the policy, legislative and institutional frameworks are yet to be developed that would support genuine CBNRM groups. Further there is need to reorient the existing institutions towards greater inclusion of diverse range of stakeholders in natural resource management.

\section{Methodology}

\section{Study design}

The study adapted a mixed methods design.

Many definitions of mixed methods are available in the literature (e.g., see Johnson, Onwuegbuzie, \& Turner, 2007) [1315]. For purposes of this study, mixed methods research was defined as a research approach or methodology:

i. Focusing on research questions that call for real-life contextual understandings, multi-level perspectives, and cultural influences

ii. Employing rigorous quantitative research assessing magnitude and frequency of constructs and rigorous qualitative research exploring the meaning and understanding of constructs;

iii. Utilizing multiple methods (e.g., intervention trials and in-depth interviews);

iv. Intentionally integrating or combining these methods to draw on the strengths of each

v. Framing the investigation within philosophical and theoretical positions.
The study design integrated both data triangulation (quantitative and qualitative) using several data sources e.g. primary and secondary sources and methodological triangulation - using multiple methods to achieve results e.g. literature review, use of focus groups, key informants and consultants observations.

\section{Approach}

A tried and tested participatory approach which engaged key stakeholders including: biodiversity conservation, wildlife management/conservation, forestry, fisheries, ecotourism, environment, water management, water, sanitation and hygiene, agriculture, livestock and climate change, opinion leaders, key informants and project beneficiaries was applied. The approach according to the TOR was supported by field visits to capture and document success stories from projects. Salient components of the methodology including initial assessments of existing project document, policies, and adaptation practices. Whilst carrying out the assignment, the consultant took cognizance of gender related and other cross-cutting development issues. The team recognizes the importance of good data collection instruments and methods as well as proper use of statistical tools for identifying and recruiting representative beneficiary groups and to tell success stories and document in still pictures and videos.

\section{Phases of the project}

The methodology involved a logical sequence of the following specific iterative activities which may be divided into three main phases:

a. Inception phase: This phase focused on desk reviews, development of standard questions and formats for data collection as well as outlines for stories and story lines for documentaries.

b. Field Study: This phase involved Data Collection/ Engagement with beneficiaries and stakeholders. It used several data gathering tools.

c. Drafting and Finalization of Deliverables: Upon completion of the field work, the team gathered to prepare the deliverables [16].

\section{Data collection methods}

The study involved use of both primary and secondary data. While secondary data was sourced from relevant literature, primary data was obtained from the selected respondents for this study. The following methods were used for data collection:

\section{Literature Review}

Secondary data was collected through literature reviews of documents that were of relevance to the project from various stakeholders. 


\section{International Journal of Environmental Sciences \& Natural Resources}

\section{Field Surveys}

Field surveys were undertaken in the project site for a period 21 days. The study focused on CBNRM groups as units

Table 1: Successful CBNRM projects assessed.

\begin{tabular}{|c|c|c|}
\hline NO & Community Group & Name Of Project \\
\hline \multicolumn{3}{|c|}{ Wildlife } \\
\hline 1 & $\begin{array}{l}\text { Golini Mwaluganje Wildlife Community } \\
\text { Conservation }\end{array}$ & Mwaluganje elephant sanctuary \\
\hline 2 & Watamu Turtle watch & Turtle Rehabilitation \\
\hline 3 & Lower Tana Conservation Trust & Wildlife conservancy \\
\hline 4 & $\begin{array}{l}\text { Lumo wildlife conservancy project in } \\
\text { Mwakitau }\end{array}$ & Wildlife conservancy \\
\hline \multicolumn{3}{|c|}{ Forestry } \\
\hline 5 & Sokoke Community forestry association & Tree Nursery \\
\hline 6 & Kenya Union for the Blind & Tree Nursery \\
\hline 7 & $\begin{array}{c}\text { Mida creek conservation Fishing and } \\
\text { Awareness Group }\end{array}$ & Tree Nursery \\
\hline 8 & Mikoko Pamoja & Hewa Kaa \\
\hline 9 & Dabaso Creek conservation project & Ecotourism project \\
\hline 10 & Jilore Community Forest association & Tree Nursery \\
\hline 11 & Jimbo Environmental Group & Mangrove conservation \\
\hline 12 & Kibokoni mangrove conservation project & Mangrove conservation \\
\hline 13 & Misitu women group & Tree Nursery \\
\hline 14 & Pate mangrove conservation group-Lamu & Wildlife conservancy \\
\hline 15 & Mvera & Mida creek community Boardwalk \\
\hline 16 & Ufanisi women Group & Herbal Medicine processing Unit \\
\hline \multicolumn{3}{|c|}{ Fisheries } \\
\hline 17 & $\begin{array}{l}\text { Kuruwitu conservation and Welfare } \\
\text { association }\end{array}$ & Kuruwitu Marine Conservation project \\
\hline 18 & Vanga Beach Management Unit & Auctioning of fish \\
\hline 19 & Wasini BMU & Wasini coral reef restoration project \\
\hline 20 & Kibuyuni BMU & Kibuyuni sea weed farming project \\
\hline 21 & Dabaso Creek conservation Group & Crab fattening project \\
\hline 22 & Takaungu BMU & Cold storage \\
\hline 23 & Bamburi BMU & Fish Depot \\
\hline 24 & Mtwapa BMU & Fish Depot \\
\hline 25 & Ihaleni/Kakuluni Conservation Group & Fish ponds \\
\hline \multicolumn{3}{|c|}{ Eco/Tourism } \\
\hline 26 & Mvera & Mida creek community boardwalk \\
\hline 27 & Wasini Women Group & Wasini Women mangrove boardwalk \\
\hline 28 & Gazi Women group & Gazi Boardwalk \\
\hline 29 & Wasini BMU & Wasini coral restoration project \\
\hline 30 & Gede Community Forestry Association & Jamii villas \\
\hline 31 & Rabai cultural village & Kaya Mudzi Muvya \\
\hline 32 & Dabaso Creek conservation project & Ecotourism project \\
\hline
\end{tabular}

of analysis. The groups were be categorized into 9 [17] sectors namely wildlife, forestry, fisheries, eco/tourism, environment, waste management water, sanitation \& hygiene, agriculture \& livestock and mining. 


\section{International Journal of Environmental Sciences \& Natural Resources}

\begin{tabular}{|c|c|c|}
\hline 33 & ENVIRONMENT & Coconut waste management \\
\hline 34 & Bundacho Youth Group & rehabilitation and landscaping \\
\hline 35 & Taita environmental initiative & Sorosion \\
\hline 36 & Tumuone mama group & waste management project \\
\hline Waste Management & Watamu Marine Association & Okoa maisha \\
\hline 37 & Lamu safi waste mgmt. project in Lamu & Waste management/Garbage collection \\
\hline 38 & Where talent lives & Rehabilitation of Kaya degraded areas and \\
\hline 39 & Miritini community waste management & establishment of commercial wood loads (314 \\
\hline 40 & AGRICULTURE \& LIVESTOCK
\end{tabular}

Experts suggested names of CBNRM groups to participate in the field surveys during a consultative forum as shown in Table 1 below. A structured questionnaire was used to obtain primary data from the relevant officials, and beneficiaries in CBNRM groups. The questionnaire also guided focus group discussions especially in the CBRM groups visited that attracted many members. Key informant discussions were also held with specific officials of the groups e.g. project coordinators, chairmen, secretaries etc. During the field study the team ensured that pictures and videos were taken to document the process. Authority in Kilifi. Experts were drawn from the following sectors: biodiversity conservation, wildlife management/ conservation, forestry, fisheries, eco/tourism, environment, waste management, water, sanitation \& hygiene, agriculture, livestock, sustainable development and climate change. The consultant presented draft criteria to participants which was discussed, refined and adapted as the criteria for identification of successful sub-projects.

\section{Data processing}

The data entry was done at a central place in tandem with data collection. After reviewing the completed questionnaires to rectify any data collection errors, the data input was made into a database to ensure quality control. Data was analysed both qualitatively and quantitatively. Qualitative data was analysed by consolidating emerging themes that emerged from the study while quantitative data was analysed using descriptive statistics and presented as charts and percentages.

\section{Results}

Community members implementing various natural resource based projects were asked to name what they perceived as the drivers to the success of their projects. Those interviewed included group members of each group visited and community members outside the project but who benefited from the project. On average, the study interviewed 400 community members. They listed community ownership, strong group cohesion, partnership with stakeholders, technical support, and availability of market for products, strong group leadership, availability of volunteer services, tangible benefits to community and good will/support from government. Rationale behind Drivers of Success.

Community ownership means that the community has accepted the project and owned it. In most cases, ownership came through membership registration by payment of a fee and participation in decision making. Ownership ensured that members came up with creative ways to raise funds to sustain the project even when donor support was not forthcoming. Strong group cohesion in most cases meant that the relationship of the members went beyond official group business to social issues. Members frequently called and visited each other's homes to find out the well-being of each other. When one group member fell sick, members visited them to find out what they can do. In one case, a male member of a group whose wife was bedridden for a period of three months received assistance from women in the group who fetched water and cleaned the house on behalf of the sick female member of the group.

Partnership with stakeholders meant that groups were able to identify other groups, donors, professionals etc. who shared in their vision and worked together to further their goals. Watamu Turtle Watch in their Turtle Rehabilitation project, for example, partnered with fishermen associations to ensure that when they sported a turtle that is hurt as they went about their fishing business, they quickly informed the project coordinator so a rescue operation could be organized. Similarly to finance such operations, the project needed funding and so they partnered with Local Ocean Trust, a private, non-profit organization committed to the protection of Kenya's marine environment. 
Technical support is necessary because most community projects are run laypeople whose levels of education are mostly below high school. These people therefore lack the knowledge required to deal with the technical issues for the project. For example, the Mikoko pamoja project. The Mikoko Pamoja Steering Group (MPSG) provides technical support to the Mikoko Pamoja Community Organization (MPCO) and the project coordinator while the project is supported by the Association for Coastal Ecosystem Services (ACES), a charity registered in Scotland. It emerged that this technical support was a major contributor to the success of this project. Similarly in Seaweed farming, KCDP has supported the seaweed farmers in the south coast in several ways: construction and setting up of seaweed model farmers (10x10 m plots) with 300 lines each; supported the construction of seaweed drying racks in Kibuyuni, Mkwiro and Funzi sites; supply of farming implements; supply of seaweed seeds; engagement of a seaweed buyer hence market and training in seaweed farming. Because the famers themselves have no capacity to perform these tasks, this may be described as technical support. The study revealed that this contributed immensely to the success of the projects [18-20].

Availability of market for products is another factor: Most of the projects that produced seedlings for sale failed because of lack of market for the seedlings. For example although the Gede Community Forest Association's Jamii Villas project had a nice hotel and accommodation facility, they hardly received any visitors because the facility was not known. Members were looking for a marketing firm that would help them market it abroad as a tourist destination. This is unlike projects like Mikoko Pamoja's Hewa Kaa (Carbon Trading) who have market for their product (Hewa kaa) for the next 20 years through ACES with whom they have signed a contract.

Table 2: Criteria for identification of successful sub projects in the Coast region.

\begin{tabular}{|c|c|c|c|}
\hline & $1=\mathrm{LOW}$ & 2=MODERATE & $3=\mathrm{HIGH}$ \\
\hline Project completion status & Ongoing & Completed & Completed and operational \\
\hline Project Outputs & $\begin{array}{l}\text { Few of the expected outputs } \\
\text { (activities project was funded to } \\
\text { undertake) have been achieved }\end{array}$ & $\begin{array}{l}\text { Most of the expected outputs } \\
\text { (activities project was funded to } \\
\text { undertake) have been achieved }\end{array}$ & $\begin{array}{l}\text { All the expected outputs (activities } \\
\text { project was funded to undertake) } \\
\text { have been achieved }\end{array}$ \\
\hline Project Outcomes - Beneficiaries & $\begin{array}{l}\text { Project benefitted only the group } \\
\text { members }\end{array}$ & $\begin{array}{l}\text { Project benefitted both group } \\
\text { members and wider community }\end{array}$ & $\begin{array}{l}\text { Project benefitted group } \\
\text { members, wider community and } \\
\text { the environment }\end{array}$ \\
\hline $\begin{array}{l}\text { Project Outcomes - What has } \\
\text { changed }\end{array}$ & $\begin{array}{l}\text { There is little change in the } \\
\text { community and/or in the } \\
\text { environment as a result of the } \\
\text { project }\end{array}$ & $\begin{array}{l}\text { There is some change in the } \\
\text { community and/or in the } \\
\text { environment as a result of the } \\
\text { project }\end{array}$ & $\begin{array}{l}\text { There is obvious notable change } \\
\text { in the community and/or in the } \\
\text { environment as a result of the } \\
\text { project }\end{array}$ \\
\hline Project Sustainability & $\begin{array}{l}\text { There are few indications of } \\
\text { sustainability }\end{array}$ & $\begin{array}{l}\text { There is sustainability from } \\
\text { external sources (donors) but } \\
\text { group does not use its resources to } \\
\text { sustain project }\end{array}$ & $\begin{array}{l}\text { There is sustainability from both } \\
\text { external sources (donors) and the } \\
\text { group (group uses its resources to } \\
\text { sustain project) }\end{array}$ \\
\hline $\begin{array}{l}\text { Project Impact }- \text { Problem } \\
\text { addressed }\end{array}$ & $\begin{array}{l}\text { Project has marginally addressed } \\
\text { a significant NRM or community } \\
\text { problem }\end{array}$ & $\begin{array}{l}\text { Project has moderately addressed } \\
\text { a significant NRM or community } \\
\text { problem }\end{array}$ & $\begin{array}{l}\text { Project has largely addressed a } \\
\text { significant NRM or community } \\
\text { problem }\end{array}$ \\
\hline Impact - Meeting objectives & $\begin{array}{l}\text { Project did not meet the expected } \\
\text { objectives (specific objectives of } \\
\text { the project) }\end{array}$ & $\begin{array}{l}\text { Project partly met the expected } \\
\text { objectives (specific objectives of } \\
\text { the project) }\end{array}$ & $\begin{array}{l}\text { Project fully met the expected } \\
\text { objectives (specific objectives of } \\
\text { the project) }\end{array}$ \\
\hline
\end{tabular}

Strong group leadership was necessary to bring group members together direct their efforts and inspire and motivate them to work hard to achieve set objectives. Most of those projects that scored the minimum 7 had lack of motivation as driver of failure. In most cases, the study found that the group lacked a leader to give direction to the members. Table 2 Poor leadership in projects like Wasini Women Group's: Wasini Women mangrove boardwalk, led to constant wrangles over money generated, projects to be undertaken, workers etc hence little progress in meeting objectives. Successful projects like Jimbo Environmental Group's Mangrove conservation project ensured a level of empowerment of its members in respect to ownership and protection of their coastal and marine resources, held regular meetings, ensured that members understood the constitution guiding the group, ensured that there was transparency in handling of fund generated by the project, and decision arrived by consensus. This ensured fair play and participation by all members.

Availability of volunteer services as a factor required that members provide services for free to ensure that project does not spend funds to undertake activities instead of re-investing the money. At Rabai Cultural Village's Kaya Mudzi Muvya project, members volunteer their time and take turns on a daily basis to ensure there are people at the village even when there are no visitors. Members spend time planting seedlings, practicing traditional songs, making carvings etc. For most of those projects that scored the minimum 7 members refused to volunteer due to lack of motivation and leadership. 
Tangible benefits to community means that the community must feel the benefits of the project for them to support it. For example for the community to see the benefits of Kaya Mudzi Muvya project which meant just living a huge chunk of land under forest and not cutting the trees, project members used funds generated from the project to build a nursery school, bring tap water for the community to use, pay school fees for children from disadvantaged families etc. Good will and support from government came out as a critical factor. This especially was true in terms of enforcement of rules by the project. At Mvera's Mida Creek Community Board walk, for example, conservation of mangroves has been made easy by the presence of KWS officers. While community vigilance will round up and catch people cutting mangroves, once caught they are handed over to the KWS police and undergo a government prosecution system. This support has meant that people know how serious it is to destroy mangroves.

\section{Project Success by Gender}

The data collected showed that there was a variation in project success based on gender with projects implemented by women being more successful as shown in figure 2 below. This is because women are more honest and would not for example misuse money meant for the project. As found out in Rabai Cultural village's Kaya Mudzi Muvya's project, women were the most consistent in coming to the village to attend to issues in the village Project Success by Amount of Funding. There was a significant positive correlation between amount of project funding and project success rate. Projects with higher funding appeared to be more successful. The mean funding size for successful community projects was approximately Ksh. 6 million. This is because with more funding, groups were able to complete the projects until they started making profits. Once members started sharing the profits, they got motivated to spend more time in the project and this ensured that they had something to take home and feed their families. Project Success by Donor Agency

It was shown that there was a significant variation in project success depending on the type of donor agency $(\mathrm{df}=3, \mathrm{~F}=11.69$, $\mathrm{p}<0.001$ ) [20]. Projects funded by NGOs had the highest success score while those funded by the community had the lowest. This is because projects funded by NGOs ensured constant flow of funds. For example Mikoko Pamoja's Hewa Kaa project has been receiving funding consistently from ACES for the last four years and will continue to do so for the next 16 years. Those funded by the community like Jilore.

\section{Community Forest Association}

Mwatate CBO, Pate Mangrove Conservation, Tuungane Challa Chini, Kilifi Chivara, Tumuone Mama Group, Taita Environmental Initiative, Kizingo Development Group which were at the bottom of the ranking because they lacked money to undertake activities. Consequently this led to lack of motivation amongst members

\section{Correlation of Results Chain Parameters with Project Success}

All the seven results chain variables demonstrated statistically significant correlation with project success. Project outcomes were the most highly correlated to project success while project status was least correlated. This means that respondents associated the success of projects more with the outcome of the projects more than with the status of the project. So that although Rabai Cultural Village's Kaya Mudzi Muvya project does not have a high status, the outcome which is conservation of the forest, presence of schools and water for the community made people view the project as most successful.

\section{Discussion And Conclusion}

Based on the above analysis, the researchers made the following conclusions

\section{Biggest drivers of success for community based projects}

Community ownership, strong group cohesion, partnership with stakeholders, technical support, availability of market for products, strong group leadership, availability of volunteer services, tangible benefits to community and good will / support from government are the biggest drivers of success for community based projects. Organizations supporting these projects therefore should emphasize these attributes to ensure success. Community ownership means that the community has accepted the project and owned it. In most cases, ownership came through membership registration by payment of a fee and participation in decision making. Ownership ensured that members came up with creative ways to raise funds to sustain the project even when donor support was not forthcoming. Strong group cohesion in most cases meant that the relationship of the members went beyond official group business to social issues. Members frequently called and visited each other's homes to find out the well being of each other. When one group member fell sick, members visited them to find out what they can do. In one case, a male member of a group whose wife was bedridden for a period of three months received assistance from women in the group who fetched water and cleaned the house on behalf of the sick female member of the group. Partnership with stakeholders meant that groups were able to identify other groups, donors, professionals etc who shared in their vision and worked together to further their goals. Watamu Turtle Watch in their Turtle Rehabilitation project for example partnered with fishermen associations to ensure that when they sported a turtle that is hurt as they went about their fishing business, they quickly informed the project coordinator so a rescue operation could be organized. Similarly to finance such operations, the project needed funding and so they partnered with Local Ocean Trust, a private, not for profit organisation committed to the protection of Kenya's marine environment. 
Technical support is necessary because most community project are run by laypeople whose levels of education was mostly below high school. These people therefore lacked the knowledge required to deal with the technical issues for the project. For example for the Mikoko pamoja project The Mikoko Pamoja Steering Group (MPSG) provides technical support to the Mikoko Pamoja Community Organization (MPCO) and the project coordinator while the project is supported by the Association for Coastal Ecosystem Services (ACES), a charity registered in Scotland. It emerged that this technical support was a major contributor to the success of this project. Similarly in Seaweed farming, KCDP has supported the seaweed farmers in the south coast in several ways: construction and setting up of seaweed model farmers (10x10 m plots) with 300 lines each, supported the construction of seaweed drying racks in Kibuyuni, Mkwiro and Funzi sites, supply of farming implements, supply of seaweed seeds, engagement of a seaweed buyer hence market and training in seaweed farming. Because the famers themselves have no capacity to do these, this may be described as technical support. The study revealed that this contributed immensely to the success of the projects.

Availability of market for products: Most of the projects that produced seedlings for sale failed because of lack of market for the seedlings. For example although the Gede Community Forest Association's Jamii Villas project had a nice hotel and accommodation facility, they hardly received any visitors because the facility was not known. Members were looking for a marketing firm that would help them market it abroad as a tourist destination. This is unlike projects like Mikoko Pamoja's Hewa Kaa (Carbon Trading) who have market for their product (Hewa kaa) for the next 20 years through ACES with whom they have signed a contract. Strong group leadership was necessary to bring group members together direct their efforts and inspire and motivate them to work hard to achieve set objectives.

Most of those projects that scored the minimum 7 had lack of motivation as driver of failure. In most cases, the study found that the groups lacked a leader to give direction to the members. Poor leadership in projects like Wasini Women Group's Wasini Women mangrove boardwalk led to constant wrangles over money generated, projects to be undertaken, workers etc hence no progress in meeting objectives. Successful projects like Jimbo Environmental Group's Mangrove conservation project ensured a level of empowerment of its members in respect to ownership and protection of their coastal and marine resources, held regular meetings, ensured that members understood the constitution guiding the group, ensured that there was transparency in handling of funds generated by the project, and decisions arrived by consensus. This ensured fair play and participation by all members. Availability of volunteer services: This required that members provide services for free to ensure that the project does not spend funds to undertake activities instead of re-investing the money. At Rabai Cultural Village's Kaya Mudzi
Muvya project, members volunteer their time and take turns on a daily basis to ensure there are people at the village even when there are no visitors. Members spend time planting seedlings, practicing traditional songs, making carvings etc. For most of those projects that scored the minimum 7 members refused to volunteer due to lack of motivation and leadership.

Tangible benefits to community means that the community must feel the benefits of the project for them to support it. For example for the community to see Figures $1 \& 2$ the benefits of Kaya Mudzi Muvya project which meant just living a huge chunk of land under forest and not cutting the trees, project members used funds generated from the project to build a nursery school, bring tap water for the community to use, pay school fees for children from disadvantaged families etc. Good will/support from government: this especially came in terms of enforcement of rules by the project. At Mvera's Mida Creek Community Board walk Conservation of mangroves has been made easy by the presence of KWS officers. While community vigilance will round up and catch people cutting mangroves, once caught they are handed over to the KWS police and undergo a government prosecution system. This support has meant that people know how serious it is to destroy mangroves.
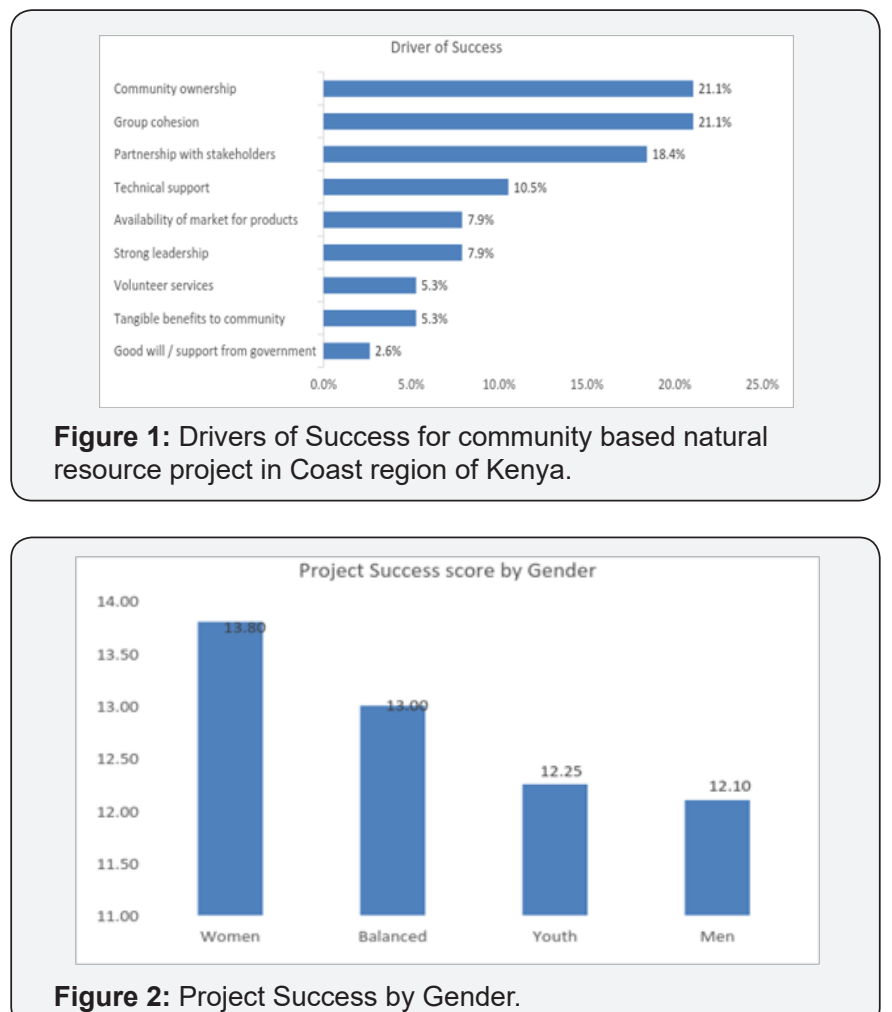

Figure 2: Project Success by Gender.

\section{Projects with greater women participation tend to perform better}

The data collected showed that there was a variation in project success based on gender with projects implemented by women being more successful as shown in the Figure 3-5. This is because women are more honest and would not for example 
misuse money meant for the project. As found out in Rabai Cultural village's Kaya Mudzi Muvya's project, women were the most consistent in coming to the village to attend to issues in it. More opportunities therefore should be given to women in these projects.
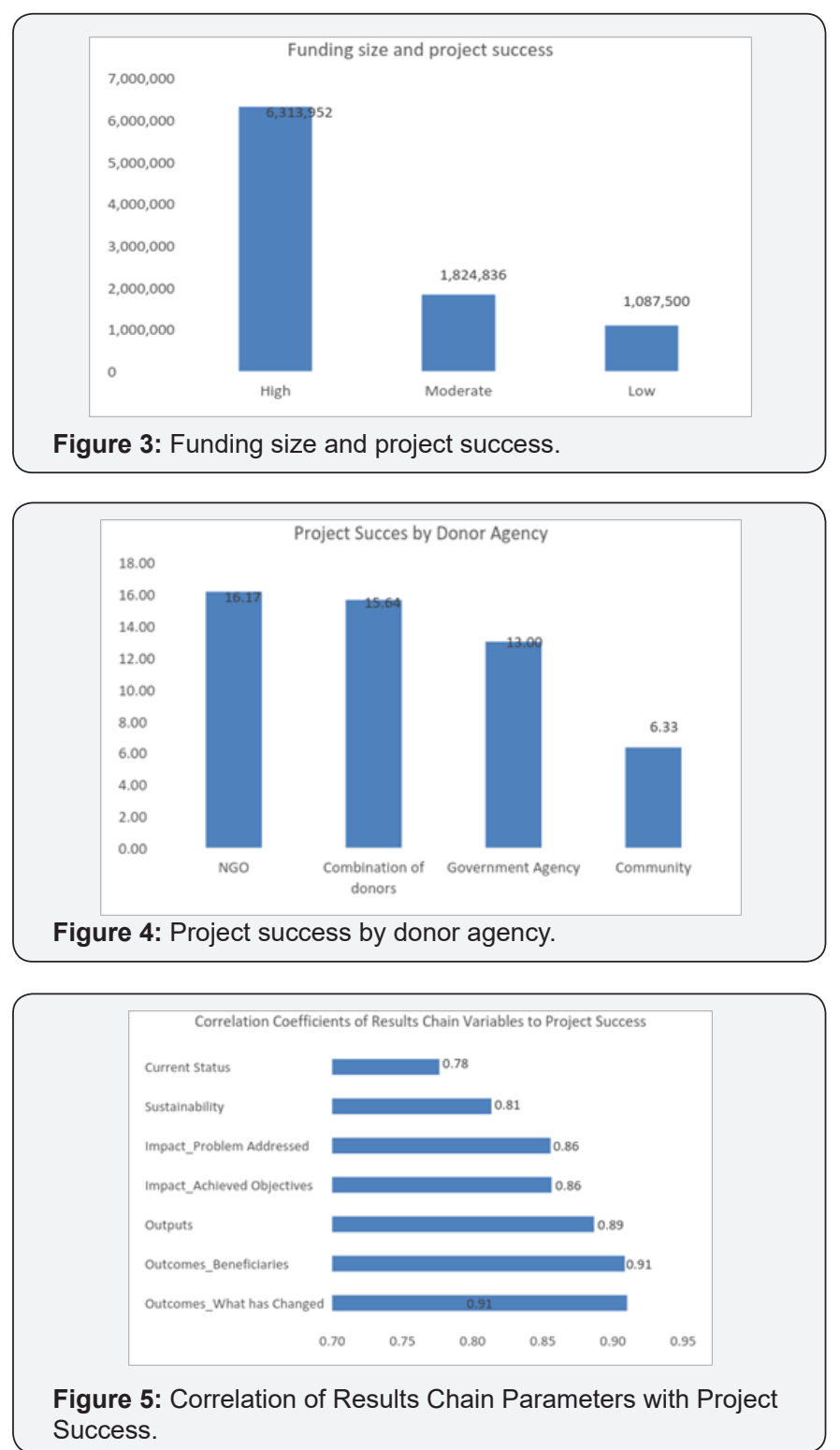

\section{Positive correlation between amount of project funding and project success rate}

The study revealed that there is a significant positive correlation between amount of project funding and project success rate. Projects with higher funding appear to be more successful with the mean funding size for successful community projects being approximately Ksh. 6 million. Projects with higher funding appeared to be more successful. The mean funding size for successful community projects was approximately Ksh. 6 million. The study revealed that with more funding, groups were able to complete the projects until they started making profits.
Once members started sharing the profits, they got motivated to spend more time in the project as this ensured that they had something to take home and feed their families. Projects should therefore be funded at those levels to ensure success.

\section{Projects funded by NGOs have the highest success rate}

Results from the study also indicate that projects funded by NGOs have the highest success score while those funded by community being the lowest. This is because projects funded by NGO ensured constant flow of funds. For example Mikoko Pamoja's Hewa Kaa project has been receiving funding consistently from ASSETS for the last four years and will continue to do so for the next 16 years. Those funded by the community like Jilore Community Forest Association, Mwatate CBO, Pate Mangrove Conservation, Tuungane Challa Chini, Kilifi Chivara, Tumuone Mama Group, Taita Environmental Initiative, Kizingo Development Group, were at the bottom of the ranking because they lacked money to undertake activities. Consequently this led to lack of motivation amongst members. This calls for more interventions by NGOs in support of community projects.

\section{Project outcomes are the most highly correlated to project success}

It may be concluded from the findings of this study that project outcomes are the most highly correlated to project success while project status is least correlated. This means that communities associate the success of projects more with the outcome of the projects than that with the status of the project. So that although Rabai Cultural Village's Kaya Mudzi Muvya project does not have a high status (income obtained is not significant, most members in the project have not gone beyond primary school etc.) , (Figure 5) the outcome which is conservation of the forest, presence of schools and water for the community makes people rate the project as most successful. This calls for emphasis on project outcomes amongst community projects. These outcomes will be most visible if the community views them as contributing to improvement of their lives.

\section{Acknowledgement}

This project was funded by The World Bank under the following

Rfp No: KCDP/RFP/05/2014-2015

Client: Kenya Marine and Fisheries Research Institute

Country: Republic of Kenya

Project Name: Kenya Coastal Development Project, KCDP

Credit no: $4801 \mathrm{KE}$

The authors would like to thank all stakeholders who participated in this project. Special thanks go to the following people:

Jacqueline Uku, Project Coordinator, Kenya Coastal Development Project; Mr. Adan Kala - Warden, Kenya Wildlife 
Service; Dr. Erick Okuku - Kenya Marine and Fisheries Research Institute; Mr. James Kamula - National Environment Management Authority; Mr. Adan Kala - Warden, Kenya Wildlife Service; Dr Mellzedeck Osore - Kenya Coastal Development Project; Dr Judith Nyunja - Kenya Wildlife Service; Mr. Stephen Mwangi - Kenya Marine and Fisheries Research Institute ; Mr. Francis Mutuku

- Kenya Coastal Development Project; Mr. Chemuku Wekesa - Kenya Forestry Research Institute; Ms. Mercy Ng'atuu Kenya Wildlife Service; Mr. Fredrick Mwambili Coast Development Authority; Ms. Jacquline Benard - Kenya Wildlife Service

\section{References}

1. WD Wildlife Division (2009) Ministry of Natural Resources and Tourism. Proceedings of a workshop on the formulation of wildlife management areas , pp.132.

2. Western D, Wright (1994) Natural Connections: Perspectives in Community-based Conservation. Washington D C: Island Press, p.12.

3. Shackleton SB, Campbel S E, Wollenberg D, Edmunds (2002) Devolution and Community Based Resource Management: Creating for local people to participate and benefit. ODI Natural Resources pp. 76.

4. Brundland G (2007) Our Common Future: The World Commission of Environment and Development. Oxford University Press, USA, pp.300.

5. Lewis D (2003) Voices from Africa: local perspectives on conservation. Washington,USA2(1):88-100.

6. Lyons A (2000) An effective monitoring framework for Community Based Natural Resource Management: A case study of The Admade Program in Zambia. A Thesis presented to the Graduate School of the University of Florida in Partial Fulfillment of The Requirements for the Degree of Master of Science University of Florida.

7. Hulme, David and Mashall Murphree (2009) "Communities, Wildlife, and the 'New Conservation' in Africa."Journal of International Development 11(2) Coast Development Authority (2006) Towards Integrated Management and Sustainable Development of Kenya's
Coast. Findings and Recommendations for an Action Strategy in the Nyali-Bamburi-Shanzu: 277-285.

8. Matiru V (2004) Community Based Natural Resource Management in Kenya. In Community Based Natural Resource Management in the IGAD region. Editors J. Awimbo, E. Barrow and M. Karaba. pp.109-141.

9. McNeely J (2005) Expanding Partnerships in Conservation. IUCN publication. Washington DC: Island Press, pp. 309.

10. McNaughton SJ (2009) "Ecosystems and Conservation in the Twentyfirst Century," in Conservation for the Twenty-first Century. New York, USA: Oxford University Press, pp. 109-120.

11. Bond I, David A, Nott C, Nott K (2006) Community-Based Natural Resource Management manual. Wildlife Management Series. The Norwegian agency for development corporation NORAD, WWFSARPO.

12. Golman M (2002) Partitioned nature, privileged knowledge: Community Based Conservation in the Maasai Ecosystem, Tanzania.34(5): 883-862.

13. Government of Kenya (2009) Kenya State of the Coast Report: Towards integrated management of coastal and marine resources in Kenya, Nairobi: NEMA, pp. 104.

14. International CBNRM workshop (2008) Washington DC, USA.

15. Kenya Coastal Development Project( 2012) Communications Strategy, Mombasa,Kenya ,P. 34.

16. Thirgood S (2004) Can parks protect migratory ungulates? The case of the Serengeti wildebeest Animal Conservation 7(2): 113-120.

17. Kenya Census, 2009, http://www.scribd.com/doc/36672705/KenyaCensus-2009.

18. http://www.bbc.com/news/world-africa-11531398

19. http://uk.reuters.com/article/2012/07/23/uk-kenya-coast-mrcidUKBRE86M0H820120723

20. http://coastalforests.tfcg.org/index.html

\section{Your next submission with Juniper Publishers will reach you the below assets}

- Quality Editorial service

- Swift Peer Review

- Reprints availability

- E-prints Service

- Manuscript Podcast for convenient understanding

- Global attainment for your research

- Manuscript accessibility in different formats

( Pdf, E-pub, Full Text, Audio)

- Unceasing customer service

Track the below URL for one-step submission

https://juniperpublishers.com/online-submission.php 